\title{
ЭМПИРИЧЕСКОЕ ИССЛЕДОВАНИЕ СУБЪЕКТИВНОГО БЛАГОПОЛУЧИЯ ПРЕПОДАВАТЕЛЕЙ КАФЕДРЫ «ФИЗИЧЕСКАЯ КУЛЬТУРА И СПОРТ» МГТУ ИМ. Н.Э. БАУМАНА
}

\section{EMPIRICAL STUDY OF THE SUBJECTIVE WELL-BEING OF TEACHERS OF THE DEPARTMENT "PHYSICAL CULTURE AND SPORT" BAUMAN MOSCOW STATE TECHNICAL UNIVERSITY \\ O. Tsyganenko O. Markova T. Velichko K. Bidordinova}

Summary: The article is devoted to the results of an empirical study of the subjective well-being of teachers in the situation of the coronavirus pandemic. The article presents questionnaires for conducting an empirical study among the teaching staff who worked remotely during the period of self-isolation. A qualitative and quantitative analysis of the results was carried out. The issue of identifying the relationship between subjective well-being and anxiety about the consequences of coronavirus and working in a remote format is considered. In particular, the issue of identifying the connection between the risk of infection during the pandemic, concern for the fate of loved ones and satisfaction with life and positive emotions is noted.

Keywords: life satisfaction, subjective well-being of teachers, anxiety, pandemic, self-isolation, coronavirus, COVID-19.
Цыганенко Олеся Сергеевна

старший преподаватель, Московский Государственный Технический Университет им. Н.Э. Баумана. ustimenko-o@mail.ru

Маркова Ольга Александровна старший преподаватель, Московский Государственный Технический Университет им. Н.Э. Баумана markovaoa75@mail.ru

Величко Татьяна Ивановна

К.б.н., доцент, Московский Государственный Технический Университет им. Н.Э. Баумана tivelichko@mail.ru

Бидординова Ксения Александровна преподаватель, Московский Государственный Технический Университет им. Н.Э. Баумана zaika666.90@mail.ru

Аннотация: Статья посвящена результатам эмпирического исследования субъективного благополучия преподавателей в ситуации пандемии коронавируса. Представлены анкеты для проведения эмпирического исследования среди профессорско-преподавательского состава, работавших дистанционно в период самоизоляции. Проведен качественный и количественный анализ полученных результатов. Рассматривается вопрос выявления связи субъективного благополучия с тревогой по поводу последствий коронавируса и работой в удаленном формате. В частности, отмечается вопрос выявления связи по поводу риска заражения в период пандемии, беспокойство за судьбу близких людей и удовлетворенностью жизнью и позитивными эмоциями.

Ключевые слова: удовлетворенность жизнью, субъективное благополучие преподавателей, тревожность, пандемия, самоизоляция, коронавирус, COVID-19.

Проблема субъективного благополучия чрезвычайно актуальна в современном мире, в общем и в российском обществе, в частности, в связи с возникшей на фоне пандемии коронавируса COVID-19 ситуацией, которая большинством исследователей считается стрессогенной, потенциально ухудшающей качество жизни личности и благополучие [4, с. 92].

Несомненно, что прежде, чем говорить о тотальном снижении качества жизни или необходимости психологической помощи необходимо выяснить, какого рода снижение качества жизни и ухудшение благополучия имеется в виду, когда идет речь о ситуации, возникшей в результате пандемии в 2020 г.

Академическая сфера деятельности и так является недостаточно привлекательной из-за относительно не- 
высокого уровня оплаты труда, частого сокращения рабочих мест, большого объема документооборота и отчетности, высокой психоэмоциональной нагрузки. Ситуации пандемии, включающая угрозу заражения, переход на цифровое обучение, самоизоляцию и другие трудности, во много раз увеличила психоэмоциональное напряжение преподавателей.

Однако, существуют люди, которые чувствуют себя благополучно в указанной профессии, что является весомым аргументом для того, чтобы изучать факторы субъективного благополучия педагогических работников [2, С. 37-38].

В начале исследования субъективного благополучия преподавателей в ситуации пандемии была поставлена цель: выявление наличия или отсутствия связи благополучия с тревогой по поводу последствий коронавируса и работой в удаленном формате. Поставленная цель предполагала решение следующих задач:

1. разработать опросник для проведения эмпирического исследования;

2. охарактеризовать выборку по уровню выраженности субъективного благополучия;

3. обсудить полученные результаты;
4. обнародовать результаты эмпирического исследования.

В качестве методики, направленной на определение субъективного благополучия респондентов, была выбрана шкала субъективного благополучия (ШСБ), представляющая собой психодиагностический инструмент для измерения эмоционального компонента субъективного благополучия (СБ) или эмоционального комфорта (ЭК) [3, С. 122-123].

Основная выборка исследования, проведенного в МГТУ им. Н.Э. Баумана среди профессорско-преподавательского состава кафедры «Физическая культура и спорт», работавших дистанционно в период пандемии коронавируса в 2020-2021 г. включила 109 человек, от 25 до 75 лет. Исследование проводилось с учетом возрастных градаций, но исключило учет гендерных различий. Количественный состав респондентов приведен ниже в таблице 1.

В таблице 2 представлены вопросы, предложенные респондентам во время эмпирического исследования.

Результаты опроса представлены ниже в таблице 3.

Таблица 1.

Количественный состав участников исследования

\begin{tabular}{|c|c|c|c|c|c|}
\hline Возрастная группа & $25-35$ & $35-45$ & $45-55$ & $55-65$ & $65-75$ \\
\hline Количество (чел.) & 18 & 17 & 43 & 17 & 14 \\
\hline Количество от общего числа (\%) & 17 & 16 & 39 & 16 & 12 \\
\hline
\end{tabular}

Опросник для проведения эмпирического исследования

\begin{tabular}{|c|l|}
\hline № вопроса & \multicolumn{1}{c|}{ Текст вопроса } \\
\hline 1 & В последнее время я часто бываю в хорошем настроении. \\
\hline 2 & Моя работа давит на меня. \\
\hline 3 & В последнее время я хорошо сплю. \\
\hline 4 & В последнее время я плохо сплю. \\
\hline 5 & Я редко скучаю в процессе своей повседневной деятельности. \\
\hline 6 & Я часто чувствую себя одинок(им)(ой). \\
\hline 7 & Я чувствую себя здоров(ым)(ой) и бодр(ым)(ой). \\
\hline 8 & Я испытываю большое удовольствие, находясь вместе с семьей или друзьями. \\
\hline 9 & Иногда я становлюсь беспокойн(ым)(ой) по неизвестной причине. \\
\hline 10 & Утром мне трудно вставать и работать. \\
\hline 11 & Я смотрю в будущее с оптимизмом. \\
\hline 12 & Я охотно меньше просил(а) бы других о чем-либо \\
\hline 13 & Мне нравится моя повседневная деятельность \\
\hline 14 & В последнее время я чрезмерно реагирую на незначительные препятствия и неудачи \\
\hline 15 & В последнее время я чувствую себя в прекрасной форме. \\
\hline 16 & Я все больше ощущаю потребность в уединении. \\
\hline 17 & В последнее время я был(а) очень рассеян(а). \\
\hline
\end{tabular}




\begin{tabular}{|c|c|c|c|c|c|c|c|c|c|c|c|c|c|c|c|}
\hline \multirow{2}{*}{$\begin{array}{c}\stackrel{N}{N} \\
\text { вопроса }\end{array}$} & \multicolumn{5}{|c|}{ Ответ «Да» } & \multicolumn{5}{|c|}{ Ответ «Нет» } & \multicolumn{5}{|c|}{ «Затрудняюсь с ответом» } \\
\hline & $25-35$ & $35-45$ & $45-55$ & $55-65$ & $65-75$ & $25-35$ & $35-45$ & $45-55$ & $55-65$ & $65-75$ & $25-35$ & $35-45$ & $45-55$ & $55-65$ & $65-75$ \\
\hline 1 & 18 & 10 & 26 & 4 & 2 & - & - & 14 & 10 & 3 & - & 7 & 3 & 3 & 9 \\
\hline 2 & - & - & 2 & - & 1 & 12 & 10 & 36 & 17 & 6 & 6 & 7 & 5 & - & 7 \\
\hline 3 & 12 & 5 & 27 & - & 2 & - & 6 & 12 & 14 & 3 & 6 & 6 & 4 & 3 & 9 \\
\hline 4 & 16 & 4 & 23 & 2 & 2 & - & 6 & 10 & 12 & 3 & 2 & 7 & 10 & 3 & 9 \\
\hline 5 & 14 & 4 & 23 & 2 & 2 & - & 6 & 8 & 14 & 2 & 4 & 7 & 12 & 1 & 10 \\
\hline 6 & - & - & 2 & - & - & 15 & 10 & 29 & - & - & 3 & 7 & 12 & 17 & 14 \\
\hline 7 & 10 & 4 & 27 & 9 & 1 & - & 6 & 9 & 6 & 6 & 8 & 4 & 7 & 2 & 7 \\
\hline 8 & 8 & 2 & 30 & 6 & 3 & - & 9 & 4 & 8 & 3 & 10 & 6 & 9 & 3 & 11 \\
\hline 9 & 12 & 2 & - & - & - & 4 & 8 & 36 & 15 & 6 & 2 & 7 & 7 & 2 & 8 \\
\hline 10 & 4 & - & - & - & - & 10 & 10 & 38 & 14 & 7 & 4 & 7 & 5 & 3 & 7 \\
\hline 11 & 17 & 12 & 26 & 6 & 3 & - & - & 16 & 8 & 1 & 1 & 5 & 1 & 3 & 10 \\
\hline 12 & 15 & 2 & 6 & - & 1 & - & 8 & 18 & 14 & 5 & 3 & 7 & 19 & 3 & 8 \\
\hline 13 & 12 & 2 & 14 & 2 & 2 & 2 & 13 & 7 & 13 & 4 & 4 & 2 & 22 & 2 & 8 \\
\hline 14 & 8 & - & - & - & - & 6 & 10 & 37 & 15 & 5 & 4 & 7 & 6 & 2 & 9 \\
\hline 15 & 12 & 12 & 18 & 2 & - & 4 & - & 16 & 12 & 6 & 2 & 5 & 9 & 3 & 2 \\
\hline 16 & 2 & - & - & - & - & 14 & 12 & 36 & 14 & 6 & 2 & 5 & 7 & 3 & 8 \\
\hline 17 & - & 6 & 2 & 2 & 1 & 18 & 4 & 33 & 12 & 4 & - & 7 & 18 & 4 & 9 \\
\hline
\end{tabular}

Результаты исследования свидетельствуют о том, что показатели негативных эмоций, проявляющихся в ситуации пандемии COVID-19, не свидетельствуют о более низком уровне позитивных эмоций у респондентов, находившихся длительное время в ситуации самоизоляции. Чувство одиночества испытывают только двое из опрошенных респондентов, что не связано с влиянием пандемии. Половина респондентов готова обращаться за помощью к окружающим, хотя делает это весьма неохотно, другая половина предпочитает искать решение проблем самостоятельно. Молодые преподаватели чаще испытывают беспокойство, по сравнению с преподавателями старших возрастных групп, сказывается отсутствие жизненного опыта.

Большинство преподавателей, принявших участие в исследовании, высоко оценивают нематериальные блага: общение с семьей, друзьями.

Таким образом, результаты опроса, анализ ответов, рефлексия по поводу ощущения социального благополучия преподавателями позволяют сделать следующие выводы:

1. концепция субъективного благополучия включает в себя, прежде всего, когнитивную оценку удовлетворенности жизнью, в целом, и ощущения удовлетворенности профессиональной жизни, в частности;

2. отсутствует связь социального благополучия с тревогой по поводу последствий коронавируса и работой в удаленном формате;

3. тревога по поводу риска заражения в период пандемии, беспокойство за судьбу близких людей не имеют прямой связи с удовлетворенностью жизнью и позитивными эмоциями.

\section{ЛИТЕРАТУРА}

1. Кислицына, 0.А. Подходы к измерению прогресса и качества жизни (благополучия) / 0.А. Кислицына //Экономический анализ: теория и практика. 2016. - № 10. - c. 28-38.

2. Клименко, Л.В. Субъективное благополучие преподавателей российских вузов. Опыт эмпирического исследования./ Л.В. Клименко, Л.С. Скачкова // Вопросы образования. - 2020, -№ 4. -с.37-63.

3. Осин, Е.Н. Краткие русскоязычные шкалы диагностики субъективного блалгополучия: психометрические характеристики и сравнительный анализ. / Е.Н. Осин, Д.А. Леонтьев // Мониторинг об-щественного мнения: Экономические и социальные перемены. - 2020. -№ 1. С. 117-142.

4. Рассказова, Е.И. Пандемия как вызов субъективному благополучию: тревога и совладание / Е.И. Рассказова, Д.А. Леонтьев, А.А. Лебедева // Консультативная психология и психотерапия. —2020. Т. 28. — № 2. С. $90-108$. 
5. Скачкова, Л.С., Факторы субъективного благополучия научно-педагогических работников: результаты фокус-групп / Л.С. Скачкова, Д.П. Щетинина, В.И. Крячко // Государственное и муниципальное управление. Ученые записки. - 2018. - № 4. - С. 138-146.

○ Цыганенко Олеся Сергеевна (ustimenko-о@mail.ru), Маркова Ольга Александровна (markovaoa75@mail.ru), Величко Татьяна Ивановна (tivelichko@mail.ru), Бидординова Ксения Александровна (zaika666.90@mail.ru).

Журнал «Современная наука: актуальные проблемы теории и практики»

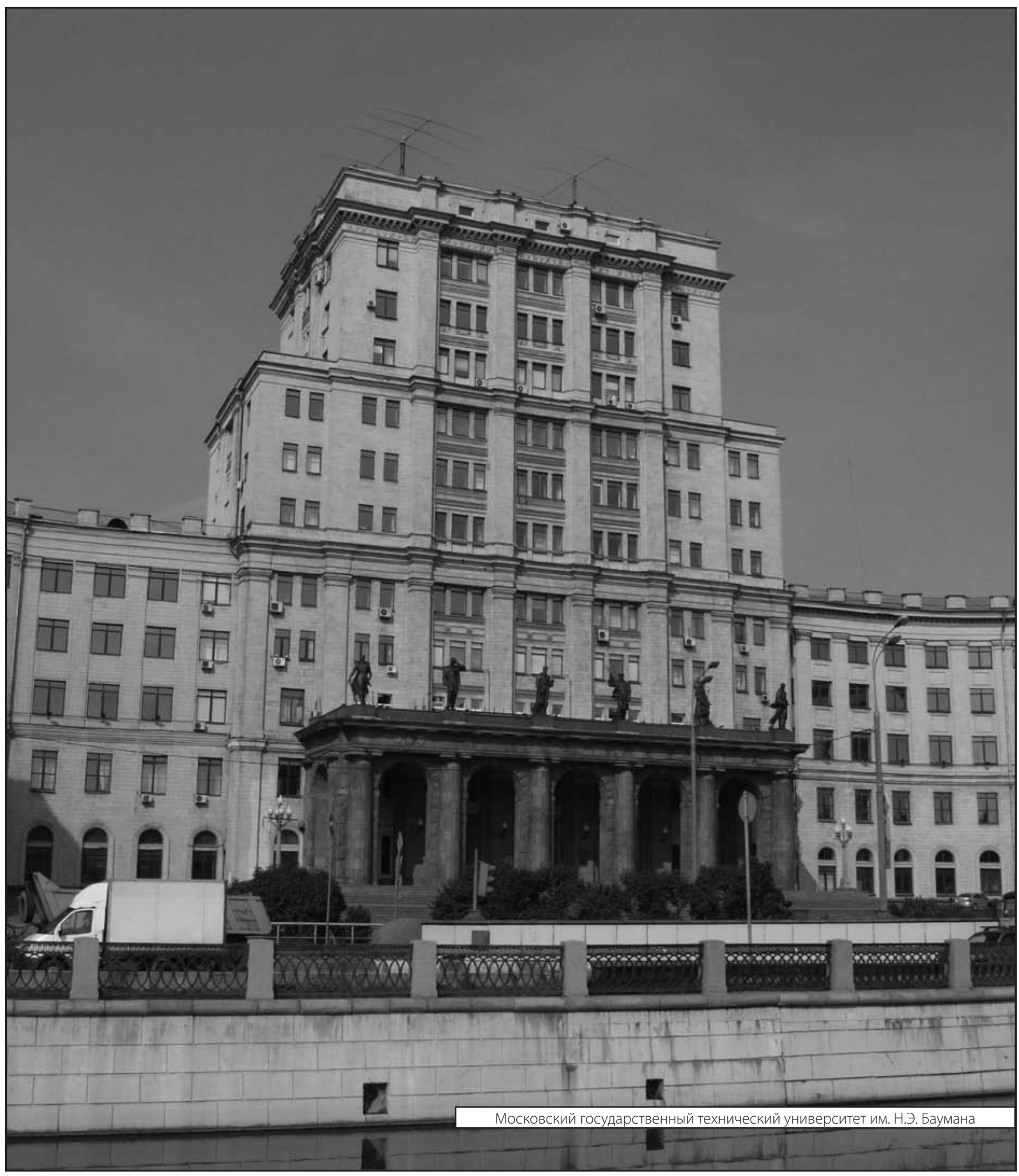

